\title{
Alkali activated cements mix design for concretes application in high corrosive conditions
}

\author{
Oleksandr Kovalchuk ${ }^{1,{ }^{*}, \text { Valentina Grabovchak }}{ }^{2}$, and Yaroslav Govdun ${ }^{1}$ \\ ${ }^{1}$ Kyiv National University of construction and Architecture, 03037 Kyiv, Povitroflotsky Avenue 31, \\ Ukraine \\ ${ }^{2}$ National Aviation University, 03058 Kyiv, Kosmonavta Komarov Avenue, 1, Ukraine
}

\begin{abstract}
This paper covers the results of development of corrosion resistant ash alkali-activated cements based on regulation of phase composition of the hydration products through changing the alkali content, content of calcium- containing cement constituents resulting in the increase strength and density of the cement stone. The results of study suggested to conclude that the cement compositions with predominance in the hydration products of weakly soluble low basic hydrosilicates of calcium, hydrogarnets and minerals similar to natural hydroaluminates exhibited the highest corrosion resistance. The results of comparison suggested to draw a conclusion that the alkali-activated cements Types APC III-400 and ACC V-400, according to National Ukrainian Standard DSTU B V.2.7, had high corrosion resistance compared to that of $\mathrm{OPC}$, thus allowing to recommend the developed cements for the concretes intended for use in aggressive environments, inclusive of sodium and magnesium sulphates and others. Coefficients of corrosion resistance of concretes are higher than 1 after even 42 months.
\end{abstract}

\section{Introduction}

With the increase in volumes of construction a first-priority issue is how to improve their durability. Durability of concrete structures is dependent upon service conditions and, among many other factors, by characteristics of the cement used for making the concrete. Of special interest is durability of corrosion resistant concretes for special intended use. Until now, there is no unified solution for the concrete mix design which would meet all needs with regard to corrosion resistant concretes. The most important characteristics which determine corrosion resistance of the concretes are: type of cement and its mineralogical composition, composition of hydration products, water to cement ratio (W/C), type of admixtures and additives, and aggregates, pore structure, etc. In the corrosion resistant concrete mix design the following factors should be taken into account: service conditions and aggressive exposure conditions.

\footnotetext{
${ }^{*}$ Corresponding author: kovalchuk.oyu@gmail.com
} 
The alkali activated cements based on granulated blast-furnace slags and fly ashes, that have been developed by a scientific school headed by Professor V.D.Glukhovsky, are the cements that can be successfully used for making corrosion resistant concretes [1-3]. The alkali activated cement concretes have high strength properties (40-120 MPa and higher), frost resistance (1000 cycles), water penetration (W10-W50), high corrosion resistance in different mineral and organic environments $[4,5]$.

Further research work allowed to develop fly ash alkali activated cements in which the fly ash content reached 90\% [6-9]. These fly ash alkali activated cements can be an important alternative to portland cements containing fly ash in a quantity of maximum $30 \%$, since in their physical-mechanical properties are similar to the portland cements, and the fly ash alkali activated cement stone is characterized by the higher weather resistance, frost- and corrosion resistance.

\section{Raw material and methods of examination}

The composition of the concrete without admixtures was constant in all experiments. Lowcalcium fly ash class F (under ASTM C 618), ground to a specific surface of $800 \mathrm{~m}^{2} / \mathrm{kg}$ by Blaine, sodium carbonate and sodium metasilicate penthahydrate as alkaline activator were used as basic raw materials. Ordinary portland cement (OPC) Type I Grade 52,5 (commercial product with a specific surface of $380 \mathrm{~m}^{2} / \mathrm{kg}$ ) and blast-furnace slag (specific surface $450 \mathrm{~m}^{2} / \mathrm{kg}$ ) were taken as additional cement constituents. Chemical composition of raw materials is shown in Table 1.

Table 1. Chemical composition of raw materials.

\begin{tabular}{|l|c|c|c|c|c|c|c|c|}
\hline Material & $\begin{array}{c}\mathrm{SiO}_{2}, \\
\%\end{array}$ & $\begin{array}{c}\mathrm{Al}_{2} \mathrm{O}_{3}, \\
\%\end{array}$ & $\begin{array}{c}\mathrm{Fe}_{2} \mathrm{O}_{3}, \\
\%\end{array}$ & $\begin{array}{c}\mathrm{CaO}, \\
\%\end{array}$ & $\begin{array}{c}\mathrm{MgO}, \\
\%\end{array}$ & $\mathrm{SO}_{3}, \%$ & $\begin{array}{c}\mathrm{Na}_{2} \mathrm{O}+\mathrm{K}_{2} \mathrm{O}, \\
\%\end{array}$ & LOI, \% \\
\hline Fly ash & 51.08 & 24.8 & 13.67 & 3.12 & 1.83 & 0.08 & $0.60+1.90$ & 1.50 \\
\hline $\begin{array}{l}\text { OPC } \\
\text { I-500 }\end{array}$ & 23.4 & 5.17 & 4.12 & 64.13 & 0.88 & 0.55 & $0.41+0.33$ & 0.20 \\
\hline Slag & 40.0 & 5.91 & 0.32 & 46.9 & 5.87 & 1.62 & - & - \\
\hline
\end{tabular}

The fly ash alkali activated cements under study, they were: alkali activated pozzolanic cement APC III and alkali activated composite cement ACC V [13] were prepared by mixing of the preliminary separately ground fly ash and slag, OPC, and alkaline activator and plasticizer in a ball mill. The slag portland cement M400 (OPC III/A), according to Ukrainian classification [14] was taken as reference. The composition of the fly ash alkali activated cements under study is given in Table 2.

Table 2. Composition of the fly ash alkali activated cements under study.

\begin{tabular}{|c|c|c|c|c|c|}
\hline \multirow{2}{*}{$\begin{array}{c}\text { Cement } \\
\text { Type }\end{array}$} & \multicolumn{5}{|c|}{ Composition, \% by mass } \\
\cline { 2 - 6 } & Fly ash & $\begin{array}{c}\text { OPC } \\
\text { I-500 }\end{array}$ & Slag & Alkaline activator & Plasticizer \\
\hline APC & 66.2 & 28.4 & - & $\mathrm{Na}_{2} \mathrm{CO}_{3}-4.7$ & 0.75 \\
\hline ACC & 54.2 & 8.9 & 26.2 & $\begin{array}{c}\mathrm{Na}_{2} \mathrm{CO}_{3}-4.7 \\
\mathrm{Na}_{2} \mathrm{SiO}_{3} \cdot 5 \mathrm{H}_{2} \mathrm{O}-5.3\end{array}$ & 0.7 \\
\hline
\end{tabular}

Corrosion resistance of the fly ash alkali activated cements under study was determined according to recommendations given in [10] by measuring strength variations of the specimens placed in aggressive environments $(10 \%$ - and $5 \%$ - solutions of sodium sulfate $\left(\mathrm{Na}_{2} \mathrm{SO}_{4}\right), 4 \%$ - and $2 \%$-solutions of magnesium sulfate $\left(\mathrm{MgSO}_{4}\right)$, concentrated sea water). 
The specimens were kept for 3 days in normal conditions, then, for 25 days - in water of technical grade. The test ages were: 30, 60, 90, 180 and 1300 days.

The corrosion resistance was expressed by a coefficient of corrosion resistance, which is calculated as a ratio between a flexural strength of the specimen after storage for 12 months in aggressive environment and flexural strength of the specimen after storage for 12 months in water. According to above recommendations the cement stone is considered to be a corrosion resistant if the coefficient of corrosion resistance after storage for 12 months is equal or higher than $(>) 0.8$.

\section{Results and discussion}

At the first stage of the study, main physical-mechanical characteristics of the fly ash alkali activated cements have been determined (Fig.1). The results of test suggested to draw a conclusion that the developed cements fall within the ranges of compressive strength requirements for the alkali activated cements APC and ACC of strength class M400 (their compressive strength was $38.4-41.3 \mathrm{MPa}$ ).

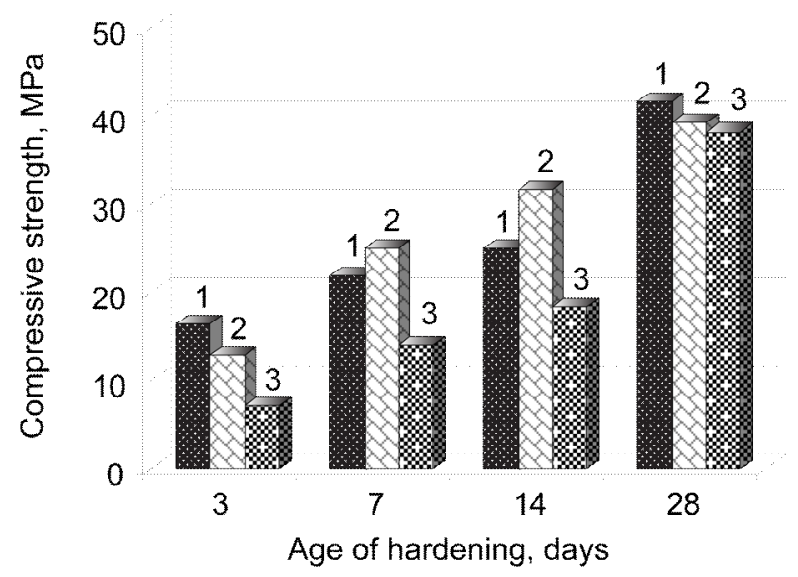

Fig. 1. Compressive strength of the cements under study: 1 - APC; 2 - ACC; 3 - OPC III/A-400.

The results of study of corrosion resistance (Fig.2, a, b, c, d, e, f,) suggested to conclude that all cements under study after long-term storage in aggressive environments at the age of 30 days have increased their strength properties comparing to the reference cement/ This can be attributed to the deepening of the hydration process. However, at the age of 2-3 months strength of the majority of the cements under study tended to lowering. So, at the age of 6 months, the cement OPC III/A-400 has rapidly lost its strength compared to the fly ash alkali activated cements APC and ACC. Thus, the cement OPC III/A-400 could not be considered as corrosion resistant cement (Fig 3). 


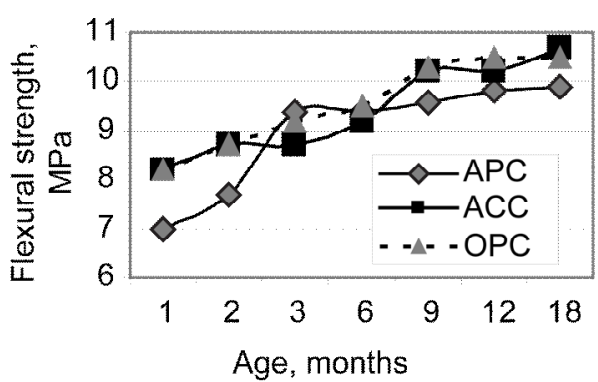

$a$

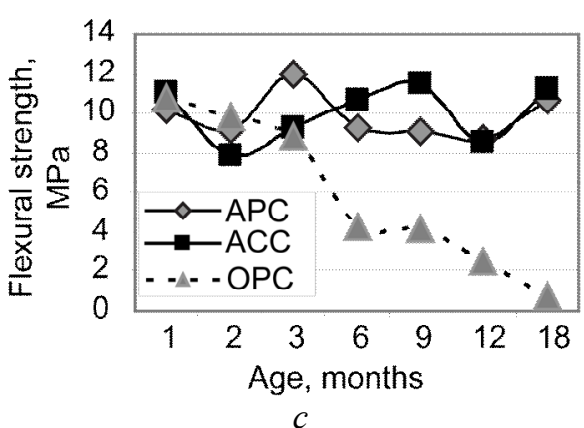

$c$

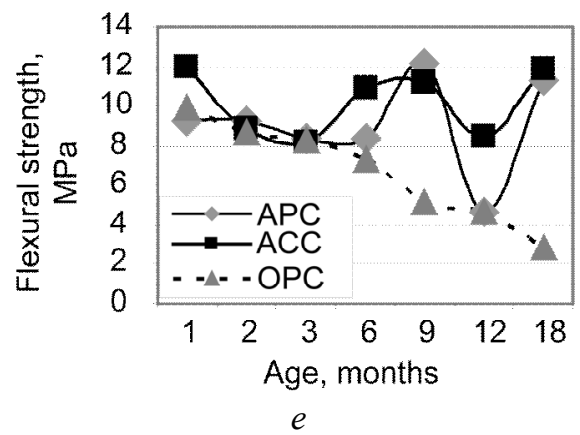

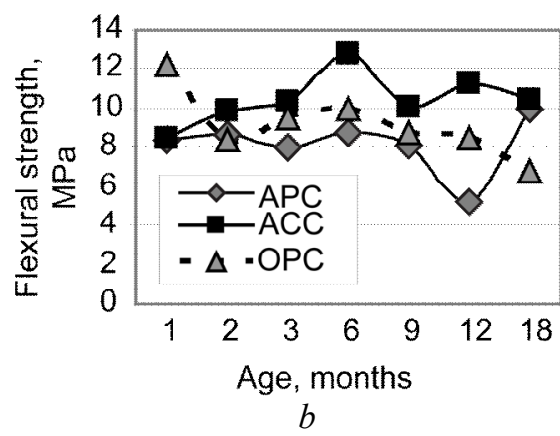
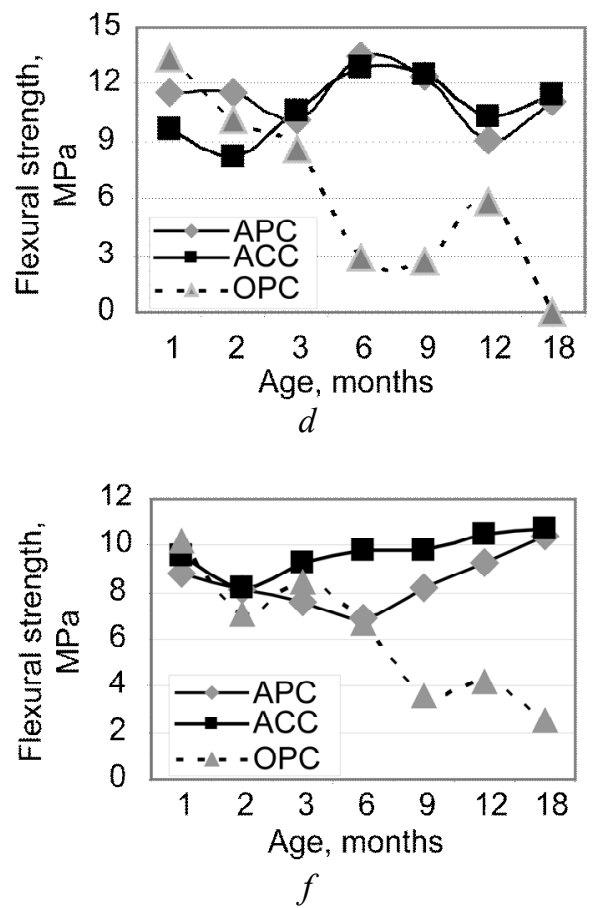

Fig. 2. Flexural strength of the cement under study vs. age (storage in aggressive environment): (a) water of technical grade; (b) sea water; (c) $\mathrm{Na}_{2} \mathrm{SO}_{4}$ (concentration- 5\%); (d) $\mathrm{Na}_{2} \mathrm{SO}_{4}$ (concentration$10 \%$ ); (e) $\mathrm{MgSO}_{4}$ (concentration- 2\%); (f) $\mathrm{MgSO}_{4}$ (concentration- 4\%).

The calculated coefficients of corrosion resistance (Table 2) suggested to draw a conclusion that the developed fly ash alkali activated cements (APC and ACC) have much better resistance against aggressive environment compared with OPC. So, at the age of 9 months, the coefficient of corrosion resistance of these cements did not lower below 1, and at the age of 12 months the developed composite cement ACC had good flexural strength (the coefficient of corrosion resistance was 1.0 and higher), and the coefficient of corrosion resistance of the developed cement APC declined below critical level only in sea water and magnesium sulfate with concentration of $4 \%$. This result can be explained by a constructive character of the combined alkaline-sulfate activation of the fly ashes [11]. 

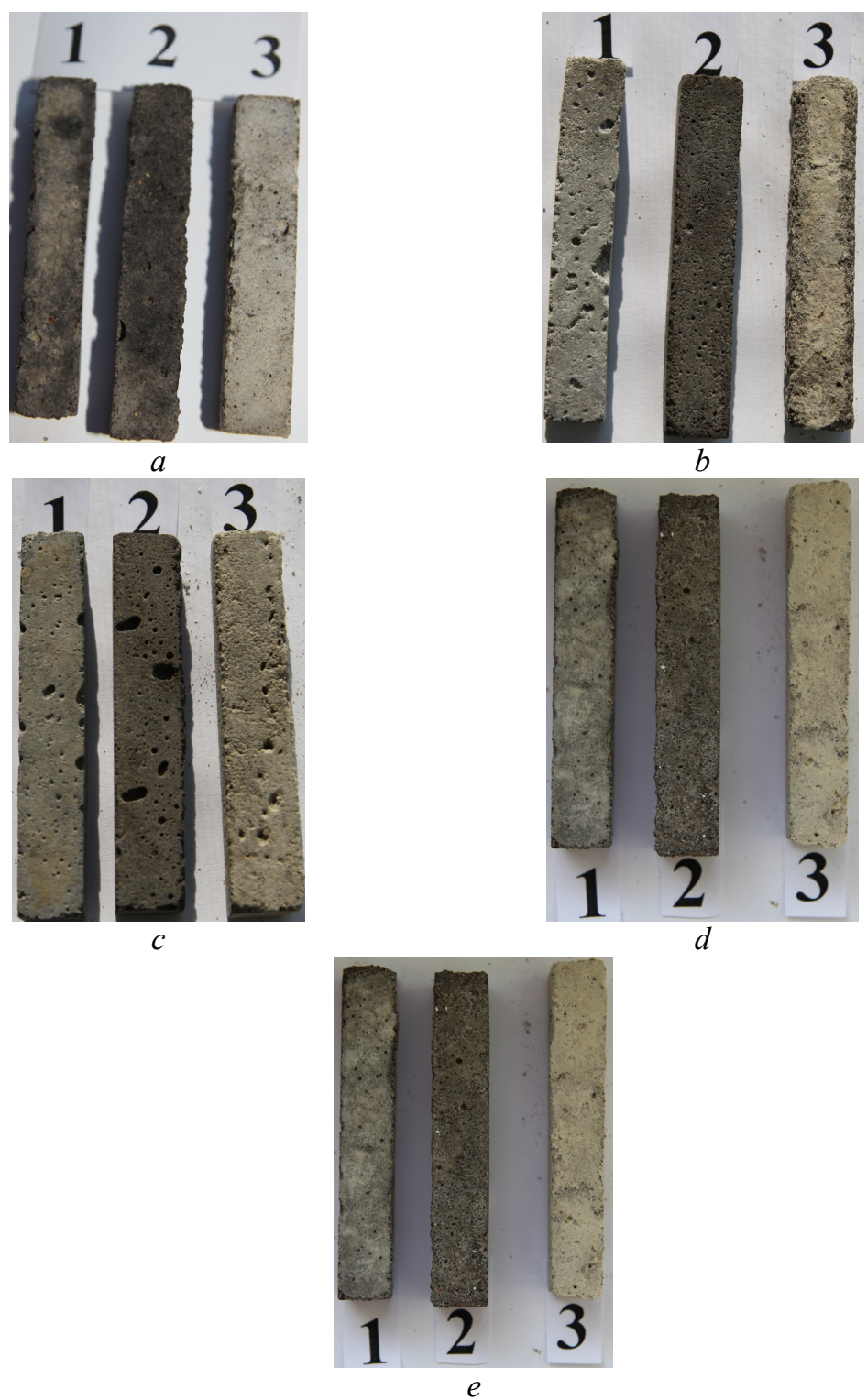

Fig. 3. Photos of the specimens after 1 year-storage in aggressive environment: (a) sea water; (b) $5 \%$ $\mathrm{Na}_{2} \mathrm{SO}_{4}$; (c) $10 \% \mathrm{Na}_{2} \mathrm{SO}_{4}$; (d) $2 \% \mathrm{MgSO}_{4}$; (e) $4 \% \mathrm{MgSO}_{4} ; 1$ - APC; 2 - ACC; 3 - OPC III/A-400.

Analyzing the coefficients of corrosion resistance (Table 3) suggested to draw a conclusion corrosion resistance of the developed fly ash alkali activated cements under study is directly proportional to a quantity of the calcium-containing cement constituents. Thus, with regard to the calcium-containing cement constituents the corrosion resistance decreases as the follows: ACC $<$ APC $<$ OPC III/A-400. With regard of different aggressive environments, the corrosion resistance decreases as follows: sea water $<$ sodium sulfate $<$ magnesium sulfate. 
Table 3. Test results of corrosion resistance of the cements under study.

\begin{tabular}{|c|c|c|c|c|c|}
\hline \multirow[t]{2}{*}{$\begin{array}{c}\text { Aggressive } \\
\text { environment }\end{array}$} & \multirow[t]{2}{*}{ Cement type } & \multicolumn{4}{|c|}{$\begin{array}{l}\text { Coefficient of corrosion resistance (Ks) } \\
\text { after storage in aggressive environment } \\
\text { days }\end{array}$} \\
\hline & & 90 & 180 & 365 & 1300 \\
\hline \multirow{3}{*}{ Sea water } & $A P C$ & 0.95 & 0.84 & 0.83 & 0.80 \\
\hline & $A C C$ & 1.39 & 0.99 & 1.22 & 1.11 \\
\hline & Slag $O P C$ & 1.05 & 0.85 & 0.85 & 0.86 \\
\hline \multirow{3}{*}{$\begin{array}{c}\mathrm{Na}_{2} \mathrm{SO}_{4} \\
\text { (concentration- } \\
5 \% \text { ) }\end{array}$} & $A P C$ & 1.00 & 0.95 & 0.88 & 1.20 \\
\hline & $A C C$ & 1.16 & 1.13 & 1.05 & 1.22 \\
\hline & Slag $O P C$ & 0.45 & 0.45 & 0.29 & 0.20 \\
\hline \multirow{3}{*}{$\begin{array}{c}\mathrm{Na}_{2} \mathrm{SO}_{4} \\
\text { (concentration- } \\
10 \% \text { ) }\end{array}$} & $A P C$ & 1.45 & 1.29 & 0.93 & 1.14 \\
\hline & $A C C$ & 1.40 & 1.23 & 1.11 & 1.10 \\
\hline & Slag OPC & 0.31 & 0.26 & 0.09 & 0.00 \\
\hline \multirow{3}{*}{$\begin{array}{c}\mathrm{MgSO}_{4} \\
\text { (concentration- } \\
2 \% \text { ) }\end{array}$} & $A P C$ & 0.90 & 1.27 & 0.84 & 1.04 \\
\hline & $A C C$ & 1.18 & 1.10 & 0.91 & 1.38 \\
\hline & Slag OPC & 0.77 & 0.50 & 0.55 & 0.78 \\
\hline \multirow{3}{*}{$\begin{array}{c}\mathrm{MgSO}_{4} \\
\text { (concentration- } \\
4 \% \text { ) }\end{array}$} & $A P C$ & 0.74 & 0.85 & 0.94 & 0.43 \\
\hline & $A C C$ & 1.07 & 0.96 & 1.13 & 0.79 \\
\hline & Slag $O P C$ & 0.71 & 0.35 & 0.50 & 0.00 \\
\hline
\end{tabular}

\section{Conclusion}

The results of study suggested to conclude that in corrosion resistance the developed fly ash alkali activated cements, they are: alkali activated pozzolanic and alkali activated composite cements exhibit the higher corrosion resistance compared to the slag portland cements and can be successfully used in making corrosion resistant concretes for the use in severe aggressive environments.

The results of study suggested to conclude that concretes on the fly ash alkali activated cements APC and ACC exhibit high corrosion resistance $(\mathrm{Ks}=1.04 \ldots 1.39$ after 12 months of storage in aggressive environments) and on the the developed composite cement ACC has the higher characteristic. At the age of 42 months slag OPC concretes were totally destroyed, thus alkali activated concretes were showing high corrosion resistance.

\section{References}

1. P.V. Krivenko, Proc. First Intern. Conf. "Alkaline Cements and Concretes, 11-129 (1994)

2. M. Sanytsky, T. Kropyvnytska, R. Kotiv, AMR, 923, $42-47$ (2014)

3. P.V. Krivenko, Proc. 10th ICCC, 4iv046-4iv050 (1997)

4. T. Naik, B.W. Ramme, J.H. Tews, Proc. 4-th Intern. Conf. on the use of Fly Ash, Silica Fume, Slag and Natural Pozzolans in Concrete, 200-210 (1992)

5. V.M. Malhotra, Concrete Admixtures Handbook (Noyes Publications, 2-nd Edition, 1995)

6. M. Sanytsky, T. Kropyvnytska, T. Kruts, O. Horpynko, I. Geviuk, KEM, 761 (2018)

7. P. Krivenko, G. Kovalchuk, O. Kovalchuk, Proc. Intern. Conf. "Global Construction: Ultimate Concrete Opportunities”, 97-104 (2005)

8. P. Krivenko, O. Kovalchuk, O. Petropavlovsky, A. Pasko, S. Lapovska, EEJET, 4/6 (94), 6-15 (2018) 
9. P.V. Krivenko, G.Yu. Kovalchuk, Proc. Internatinal Conference Alkali Activated Materials - Research, Production and Utilization, 349-367 (2007)

10. DSTU B.V.2.6-145:2010. Protection of concrete and reinforced concrete structures from corrosion. National standard of ukraine

11. O.S. Kavalerova, E.K. Pushkarova, V.I. Gots, G.YU. Kovalchuk, Proc. 16th Internat. Conf. "Ibausil", 1-0933 - 1-0940 (2006)

12. J. Stark, Alkali-Kieselsaure-Reaktion (2007)

13. DSTU B.V. 2.7-181:2009. Alkaline cements. Specifications. National standard of ukraine

14. DSTU B.V. 2.7.-46-96. Building materials. Common cements. Specifications. National standard of ukraine

15. W. Schroeyers, P. Krivenko, A. Pasko,. JER, 168, 21-29 (2016)

16. P. Krivenko, O. Kovalchuk, A. Pasko, CBMa, 151, 819-826 (2017)

17. M.M. Alonso, A. Pasko, C. Gasco, CBM, 159, 745-754 (2017)

18. P. Krivenko, O. Kovalchuk, A, Pasko, KEM, 761, 35-38 (2018)

19. P. Kryvenko, H. Cao, O. Petropavlovskyi, L. Weng, O. Kovalchuk, EEJET, 1(6), 40-45 (2016)

20. P. Krivenko, O. Kovalchuk, O. Petropavlovsky, A. Pasko, S. Lapovska, EEJET, 4/6 (94), 6-15 (2018)

21. P. Krivenko, O. Petropavlovsky, O. Kovalchuk, EEJET, 1/6(91), 33-39 (2018)

22. G. Kochetov, T. Prihna, O. Kovalchuk, D. Samchenko, EEJET, 3/6(93), 52-60 (2018)

23. R.F. Runova, M.O. Kochevyh, I.I. Rudenko, Proc. International Conference on Admixtures - Enhancing Concrete Performance, 149-156 (2005) 